\author{
KATARZYNA JANCZARSKA-BERGEL \\ Uniwersytet Pedagogiczny w Krakowie, Polska \\ Pedagogical University of Cracow, Poland
}

\title{
Turystyka jako jeden z czynników rozwoju regionalnego departamentu Vaucluse w południowo-wschodniej Francii
}

\section{Tourism as One of Factors of Regional Development of the Department of Vaucluse in South-Eastern France}

\begin{abstract}
Streszczenie: Celem artykułu jest przedstawienie turystyki jako głównego czynnika wpływającego na rozwój regionu, jakim jest mały departament Vaucluse w południowej Francji. Na powodzenie rozwoju tej dziedziny wpływa głównie konkurencyjność turystyczna regionu na tle innych, co w tej niezwykle bogatej w atrakcje części Francji (Region Prowansja-Alpy-Lazurowe Wybrzeże) jest trudne do osiągnięcia przez małe miejscowości. Jednakże miasta wchodzące w skład departamentu Vaucluse, takie jak Orange, Awinion, Gordes czy Vaisonla-Romaine, umiejętnie wykorzystują swój potencjał ekonomiczny dzięki turystyce wypoczynkowej, rozrywkowej, a nawet sportowej (Malaucene koło Mont Ventoux). Opracowanie danych statystycznych zawartych w corocznych zestawieniach, kwerenda literatury oraz indywidualne obserwacje autorki umożliwiły przedstawienie nowoczesnego podejścia do wykorzystania turystyki w ekonomicznym rozwoju obszaru. Podczas analizy możliwości przemysłu turystycznego Vaucluse zbadano m.in. bazę hotelową, atrakcyjność wypoczynkową oraz uśredniony czas pobytów. Artykuł przedstawia również najważniejsze aspekty wpływające na atrakcyjność turystyczną Vaucluse wraz ze wskazaniem destynacji turystów z Europy, ale również spoza niej.
\end{abstract}

\begin{abstract}
The aim of the article is to present tourism as the main factor influencing development of the region of the small department of Vaucluse in the southeast of France. The success of development of this realm is influenced mainly by tourism competitiveness of this region in comparison to other regions, which in this part of France unusually full of attractions (the region of Provence, the Alps, the French Riviera) is a difficult challenge for small communes. However, communes being part of the Vaucluse department such as Orange, Awinion, Gordes, or Vaison-la-Romaine skillfully use their economic potential thanks to recreational, entertainment, or even sport tourism (Malaucene at the foot of Mont Ventoux). Preparing statistical data included in annual summary statements, literature review and author's individual observations allowed to present modern approach to the use of tourism in economic development of the area. In the analysis of Vaucluse tourism industry capability among others hotel infrastructure, recreational attractiveness and average duration of stay were analysed. The article presents also the most important aspects influencing tourist attractiveness of Vaucluse, as well as indicates main destinations of tourists from Europe but also beyond.
\end{abstract}

Słowa kluczowe: Francja; konkurencyjność regionalna; rozwój regionalny; sektor turystyczny, turystyka w rozwoju społeczno-ekonomicznym

Keywords: France; regional competitiveness, regional development; tourism industry; tourism in socio-economic development 
Otrzymano: 8 grudnia 2018

Received: 8 December 2018

Zaakceptowano: 14 lutego 2019

Accepted: 14 February 2019

Sugerowana cytacja/ Suggested citation:

Janczarska-Bergel, K. (2019). Turystyka jako jeden z czynników rozwoju regionalnego departamentu Vaucluse w południowo-wschodniej Francji. Prace Komisji Geografii Przemysłu Polskiego Towarzystwa Geograficznego, 33(1), 178-187. https://doi.org/10.24917/20801653.331.14

\section{WSTĘP}

Francja jest państwem niezwykle różnorodnym pod względem religijnym, kulturowym, ale i geograficznym. Ten bogaty pod każdym względem obszar, leżący głównie w zachodniej części Europy, może pochwalić się potężnym zasobem zabytków, ruin, zamków, katedr, pięknych plaż na północy i południu kraju, a także wieloma malowniczymi i ciągnącymi się kilometrami pasmami górskimi. Nie dziwi więc, że nieprzerwanie od lat osiemdziesiątych XX wieku plasuje się w czołówce najchętniej odwiedzanych rejonów turystycznych na świecie (Dorocki, Brzegowy, 2013). Turystyka we Francji jest jednym z sektorów przynoszących najwięcej korzyści dochodowych dla narodowej gospodarki, ale i najprężniej rozwijającym się czynnikiem wpływającym na rozwój ekonomiczny kraju. Sam przemysł turystyczny definiowany jest jako wszystkie procesy o charakterze komercyjnym związane z turystyką, obejmujące sferę usług oraz branżową produkcję materialną (Łazarek, 1999). Każdy z regionów oferuje coraz większy i nowocześniejszy wachlarz atrakcji i usług, zachęcający do podjęcia wypraw turystycznych w obrębie kraju, ale i przyciągający turystów z zagranicy.

W atrakcyjności i związanej z tym konkurencyjności regionów mniejszym departamentom bardzo trudno jest rywalizować o turystę, zwłaszcza gdy samo położenie nad morzem i idący za tym krajobraz przyrodniczy nie może być główną przyczyną ruchu turystycznego. Duży odsetek turystów, przede wszystkim z zagranicy, daje możliwość napływu kapitału - a tym samym rozwoju regionalnego obszaru. Rozwój regionalny tłumaczony jest jako długotrwały proces ukierunkowanych zmian, w których wyróżnia się następujące po sobie w sposób prawidłowy etapy przemian, wskazujące na zróżnicowanie obiektu pod wcześniej określonym względem. Warto zaakcentować, że wspomniane zmiany powinny mieć charakter pozytywny, aby rozwój regionalny mógł przynosić korzyści (Głuszczuk, 2011).

Znaczenie turystyki w rozwoju regionalnym jest proporcjonalne do potencjału turystycznego, jaki może zaprezentować dany obszar. Jego składowymi są m.in.: walory środowiskowe, zagospodarowanie turystyczne, infrastruktura, komunikacja, inwestycje, upowszechnianie turystyki, kapitał ludzki oraz dostępność funduszy zagranicznych (Januszewska, Nawrocka, 2015). Współcześnie do triady przekształceń (przyrodniczych, gospodarczych i społecznych) dodaje się również koncepcję trwałego i zrównoważonego rozwoju. Koncepcja ta umożliwia postęp społeczno-gospodarczy z poszanowaniem lub wręcz z poprawą jakości środowiska przyrodniczego (Markowski, 2008). Bardzo często zwraca się uwagę na konieczność innowacyjności w sektorze turystycznym, gdyż to właśnie dzięki niej możliwy jest współcześnie wzrost gospodarczy. We Francji fakt ten dotyczy przede wszystkim regionów atrakcyjnych turystycznie (Delekta, Dorocki, Zdon-Korzeniowska, 2012). 
Celem niniejszego artykułu jest przedstawienie turystyki jako czynnika mającego wpływ na rozwój regionalny departamentu Vaucluse w południowo-wschodniej Francji w odniesieniu do konkurencyjności regionu i innowacyjności zastosowanych rozwiązań. Turystyka, będąca coraz prężniej rozwijającym się sektorem, może znacząco wpłynąć na wzrost ekonomiczny, stworzenie miejsc pracy oraz rozwój infrastruktury drogowej i hotelowej małych regionów, niemogących konkurować gospodarczo z wielkimi obszarami przemysłowymi. Pochylono się również nad najważniejszymi destynacjami turystycznymi w tym obszarze, niosącymi za sobą napływ kapitału międzyregionalnego i zagranicznego. Rozwój sektora turystycznego przedstawiono dzięki analizie informacji statystycznych pozyskanych z francuskich baz danych oraz kwerendzie największych portali internetowych o tematyce turystycznej we Francji.

\section{PoŁożenie VAuCluse}

Vaucluse jest jednym z 96 departamentów metropolitarnej Francji, oznaczonym liczbą 84. Położony w południowo-wschodniej części kraju wchodzi w skład większego regionu o nazwie Prowansja-Alpy-Lazurowe Wybrzeże. Od północy graniczy z departamentami Ardéche (07) i Drôme (26), od wschodu i południowego wschodu kolejno z Alpami Górnej Prowansji (04) oraz Var (83), od południa z Deltą Rodanu (13) i od zachodu z Gard (30). Ze względu na położenie cechuje go przede wszystkim ciepły klimat śródziemnomorski (wpływ sąsiadującego od południa Morza Śródziemnego) z elementami klimatu górskiego w północnej części. Niejednolity klimat daje duże spektrum możliwości w stosunku do różnorodności atrakcji turystycznych, jakie może zaproponować Vaucluse potencjalnym turystom. Usytuowanie departamentu pomiędzy plażami Lazurowego Wybrzeża a regionem typowo górskim sprawia, że Vaucluse musi podnosić swoją konkurencyjność na tle innych regionów, aby w przyszłości nie okazać się jedynie obszarem tranzytowym dla turystów zmierzających do innych części Francji. Obecnie jest to miejsce przyjmujące co roku dużą liczbę turystów nie tylko z kraju, ale i z zagranicy. Najczęściej odwiedzanymi miastami regionu są Orange, Isle sur la Sorgue, Gargas, Vaison la Romaine i najsłynniejszy z nich wszystkich Awinion.

\section{TURYSTYKA VAUCLUSE}

Według danych z 2017 roku z Departamentalnej Agencji Rozwoju Vaucluse (Agence Départementale de l'Attractivité de Vaucluse), departament odwiedzają rocznie ponad 4 mln turystów. Liczba rezerwowanych noclegów w tymże roku przekroczyła $20 \mathrm{mln}$, co w stosunku do 2016 roku charakteryzowało się wzrostem o blisko 5\%. Sama branża hotelowa odnotowała 2\% wzrostu noclegów, głównie dzięki powrotowi klientów zagranicznych, zadowolonych z jakości i komfortu oferowanej w regionie bazy noclegowej. Warto wspomnieć, iż oceny wystawiane przez turystów po pobycie w obiektach hotelowych zlokalizowanych w Vaucluse bardzo często (w skali od 1 do 10) oscylują wokół maksymalnej możliwej do uzyskania liczby punktów (dane z booking.com). Pod uwagę podczas oceniania brane są takie kryteria, jak: czystość, komfort, atrakcyjność, jakość, wyposażenie oraz odległość od restauracji czy sklepów.

Sfera kulturalna Vaucluse również zanotowała poprawę - o 3\% więcej turystów w stosunku do roku poprzedniego jest zainteresowanych zwiedzaniem najważniejszych miejsc historycznych i zabytków, a co za tym idzie, są gotowi wesprzeć swoim 
kapitałem ich rozwój oraz odnowę. Region z roku na rok inwestuje duży kapitał w rozbudowę i renowację obiektów cieszących się dużym zainteresowaniem turystycznym. W zakresie turystyki wewnętrznej, stanowiącej $65 \%$, najczęściej region ten odwiedzają mieszkańcy Paryża i okolic, Rhône, Hauts de Seine oraz Isére. Korzystna infrastruktura transportowa we Francji daje możliwość sprawnego i relatywnie szybkiego przemieszczania się międzyregionalnego również w celu krótkich jedno- lub dwudniowych wycieczek z miejscowości oddalonych o kilkaset kilometrów. W turystyce zagranicznej głównymi odwiedzającymi są turyści z Belgii, Holandii, Wielkiej Brytanii i Niemiec. W mniejszej skali, ale coraz częściej aktywnymi turystami regionu są również mieszkańcy Europy Środkowej - Polacy, Czesi czy Słowacy.

Agencja Rozwoju podaje, że ponad 8,5\% departamentalnego PKB stanowi właśnie aktywność turystyczna, co daje ponad 557 mln euro korzyści ekonomicznych rocznie. Główne działania w zakresie turystyki reprezentowane są przez miejsca gastronomiczne oraz zakwaterowanie turystyczne. Vaucluse ma ponad 16 tys. miejsc pracy w turystyce - odpowiada to 7,5\% całkowitego zatrudnienia we wszystkich sektorach. Ciągły rozwój turystyczny i podnoszenie jakości usług w konsekwencji przyciąga turystów z całego świata, a w późniejszym okresie wpływa na konieczność poszerzania oferty turystycznej. Nowe lokale gastronomiczne i hotele to kolejne miejsca pracy dla miejscowej ludności.

Według Institut National de la Statistique et des Études Économiques (INSEE) najczęściej wybieraną formą zakwaterowania w tym regionie są hotele - w roku 2017 ponad 1,3 mln klientów wybrało właśnie ten sposób nocowania. W Vaucluse zarejestrowane jest 236 hoteli z przewagą dwu- i trzygwiazdkowych. Kempingi również są bardzo popularną opcją nocowania - ponad 360 tys. turystów skorzystało z 86 obiektów tego typu. Podobnie jak w przypadku hoteli, dominują kempingi o klasie dwui trzygwiazdkowej. Należy jednak zaznaczyć, że jakość ich zdecydowanie przewyższa te tworzone w Polsce, zarówno pod kątem komfortu, jak i atrakcyjności. Dostosowane są one przede wszystkim do samochodów turystycznych typu camper popularnych we Francji, Włoszech i Niemczech. Ostatnią, najmniejszą grupę tworzą inne możliwości zakwaterowania, jak np. schroniska dla młodzieży, domy rodzinne i turystyczne - zostało ich w sumie zgłoszonych 28 (ryc. 1). Średni czas wykupionego pobytu zależnie od miejsca wynosi kolejno dla hoteli - 1,7 doby, a dla kempingów 4,8 (od stycznia do września). W okresie letnim zwiększa się odpowiednio do wartości 1,9 i 5,8 (La fréquentation touristique, 2018).

Branża gastronomiczna charakteryzuje się wysokim poziomem świadczonych usług oraz dbałością o klienta. Liczba restauracji zlokalizowana w regionie umożliwia przyjęcie dużej liczby turystów w jednym czasie. Jakość oferowanego jedzenia i możliwość skosztowania potraw oraz win regionalnych jest jedną z wielu atrakcji tego departamentu. Dzięki tysiącom turystów odwiedzających to miejsce przemysł winny i związana z nim wszelka infrastruktura (piwnice win, winiarnie czy targi) z roku na rok coraz bardziej się rozwijają. Lokalni producenci win zdają sobie sprawę z faktu, że tylko innowacyjne podejście i dbanie o jakość produktów mogą uczynić ich konkurencyjnymi na tle innych departamentów.

Vaucluse poza historycznym miastem Awinion charakteryzuje się wieloma innymi atrakcjami turystycznymi w postaci zabytków dziedzictwa kulturowego, malowniczych wiosek, naturalnych krajobrazów, ogrodów, lokalnych produktów, rekreacyjnych tras rowerowych i pieszych, nie zapominając o wielu festiwalach odwiedzanych przez 
Ryc. 1. Liczba obiektów noclegowych w Vaucluse z uwzględnieniem ich standardu w 2017 roku

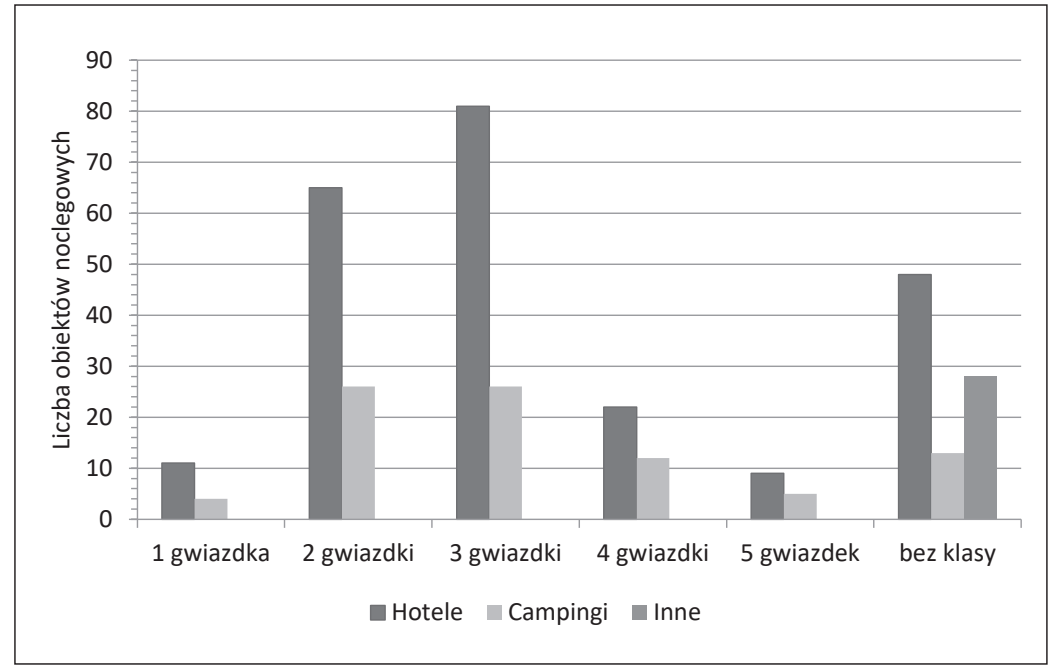

Źródło: opracowanie własne na podstawie danych z INSEE

turystów z całego świata. Bardzo często to właśnie dzięki powstaniu funkcji rekreacyjnej i sportowej w danym miejscu możliwy jest rozwój miasta, którego dostosowanie infrastruktury ściśle do potrzeb sezonowych turystów przynosi duże korzyści ekonomiczne.

Przykładem tego typu miejscowości jest Malaucene koło góry Mont Ventoux (Góra Wiatrów). Sama góra, poza punktem widokowym na Morze Śródziemne, Alpy i Pireneje, jest - w zależności od sezonu - latem ośrodkiem kolarstwa, a zimą - narciarstwa. Miejsce zasłynęło w 1951 roku, gdy po raz pierwszy przeprowadzono tu jeden z etapów wyścigu kolarskiego Tour de France. Stało się to bodźcem do powstania miejsc noclegowych oraz gastronomicznych dla turystów korzystających z wyciągów narciarskich, ale i chcących wziąć udział w organizowanych konkursach wjazdu kolarzy na sam szczyt. Ponadto zaznaczyło się przebranżowienie usług oferowanych w miejscowościach otaczających Górę Wiatrów - rozwinęło się wiele punktów oferujących rowery i ich części, narty czy wszelkie usługi z nimi związane. Jest to klasyczny przykład umiejętnego dostosowania przemysłu i infrastruktury do warunków i możliwości turystycznych występujących na danym obszarze. Ewolucja tego rejonu w ośrodek turystyczno-sportowy poza napływem kapitału z ruchu turystycznego wpłynęła także na powstanie wielu miejsc pracy zarówno dla mieszkańców Malaucene, jak i miejscowości sąsiadujących.

Najważniejszym w omawianym departamencie czynnikiem przyciągającym turystów są miejsca zabytkowe i kulturalne. Wprowadzenie specjalnych biletów umożliwiających zwiedzanie kilku obiektów czy nowoczesnych przewodników audio i wideo pozwala połączyć odległą przeszłość z teraźniejszością. Bardzo często w wielu obiektach organizowane są festiwale tematyczne, przybliżające przeciętnemu turyście historię miejsca, w którym się znajduje. Współcześnie wykorzystywane są techniki umożliwiające wielozmysłowe uczestnictwo w danym wydarzeniu (wizualizacja 3D, rozszerzona rzeczywistość, możliwość posmakowania potraw itd.). Rocznie notowanych jest ponad 2 mln odwiedzających - z tendencją wzrostową, gdyż frekwencja ta w stosunku do 2016 roku zwiększyła się o 3\%. W czołówce najczęściej odwiedzanych miast plasuje 
się Awinion ze znanym na całym świecie Pałacem Papieży i Mostem św. Bénzeta. Kolejne miejsce zajmuje Orange z teatrem antycznym. Warto wspomnieć, że miejsce to jest dużo lepiej zachowane i zdecydowanie bardziej zadbane niż podobny obiekt w pobliskim Nimes (znajdujący się w sąsiadującym departamencie Gard). Inne - z mniejszą liczbą odwiedzin, ale w dalszym ciągu popularne wśród turystów - to: Muzeum Archeologiczne w Vaison la Romaine, Muzeum Lawendy na obrzeżach Awinionu oraz zamek w Lourmarin. Najczęściej odwiedzane miejsca wraz z liczbą turystów zostały zestawione w tab. 1.

Tab. 1. Najczęściej zwiedzane przez turystów obiekty w departamencie Vaucluse w 2017 roku

\begin{tabular}{|l|l|c|}
\hline \multicolumn{1}{|c|}{ Obiekt } & \multicolumn{1}{|c|}{ Miasto } & Liczba odwiedzających \\
\hline Pałac Papieży & Awinion & 598085 \\
\hline Most św. Bénezeta & Awinion & 397946 \\
\hline Teatr antyczny & Orange & 175000 \\
\hline Muzeum Archeologiczne & Vaison la Romaine & 68244 \\
\hline Muzeum Lawendy & Awinion & 66295 \\
\hline Zamek Lourmarin & Lourmarin & 47190 \\
\hline Fondation Villa Datris G & Isle sur la Sorgue & 35000 \\
\hline Muzeum Okhra & Roussillon & 33401 \\
\hline Kopalnia Bruoux & Gargas & 32380 \\
\hline Muzeum Cavalet & Awinion & 25878 \\
\hline Muzeum Lapidaire & Awinion & 22296 \\
\hline $\begin{array}{l}\text { Muzeum narzędzi plantatorów } \\
\text { winorośli }\end{array}$ & Châteauneuf-du-Pape & 18399 \\
\hline Opactwo św. Hilaire & Menerbes & 12500 \\
\hline Pałac Roure & Awinion & 12363 \\
\hline Katedra Notre Dame & Cavaillon & 11012 \\
\hline
\end{tabular}

Źródło: opracowanie własne na podstawie danych z Le tourisme en Vaucluse (2018)

Pałac Papieży jest atrakcją ściągającą turystów nie tylko z powodu piękna architektury oraz dużego znaczenia historycznego. W zwiedzaniu obiektu zastosowano innowacyjną technikę „HistoPad”, popularyzującą nowoczesny i zarazem efektywny sposób przekazywania wiedzy. Za pomocą cyfrowego tabletu uczestnik wycieczki może na własne oczy zobaczyć, jak dawniej wyglądał zamek. Rozszerzona rzeczywistość w połączeniu z zabawą i interakcją umożliwia dużo ciekawsze przekazywanie informacji niż w standardowym muzeum. W ofercie jest możliwość wyboru języka, w jakim wirtualny przewodnik będzie nas oprowadzał po obiekcie. Większość zabytków w tym rejonie jest obsługiwana przez przewodniki audio, podobnie jak specjalnie zorganizowane turystyczne przejazdy po miastach Vaucluse. Jednakże w szerokim zakresie języków dostępnych dla turystów nie ma w dalszym ciągu polskiego - pomimo rosnącej liczby osób przyjeżdżających w to miejsce z Polski. Co ciekawe, poza oczywistym językiem niemieckim, angielskim, włoskim czy hiszpańskim, spotkać się tu można z rosyjskim, japońskim czy nawet czeskim.

Pałac jest bardzo dobrze utrzymany, podobnie jak inne zabytki w Awinionie miasto zdecydowanie poświęca spore fundusze na odnowę i renowację swojego dziedzictwa kulturowego. Jest to jeden z głównych celów zapisanych w strategii rozwoju departamentu - w teraźniejszości i w przyszłości. Całe stare miasto otoczone jest 
silnie rozbudowaną infrastrukturą hotelową oraz gastronomiczną, co w obliczu dużego zainteresowania turystów z całego świata przynosi duże zyski ekonomiczne. Awinion jest miastem rozwijającym się nie tylko pod względem turystycznym, o czym świadczy chociażby kosztowne przedsięwzięcie, jakim na chwilę obecną jest budowa infrastruktury tramwajowej. Zamysłem tego projektu jest transport społeczności lokalnej, a także sprawne i szybkie przemieszczanie się turystów podczas imprez masowych. Turystyka w tym przypadku jest bodźcem do poszerzania możliwości transportowych oferowanych przez miasto, które w połączeniu z istniejącymi parkingami park and ride może zdecydowanie usprawnić ruch uliczny. Również część związana z festiwalami oraz wydarzeniami kulturalnymi przyciąga szerokie rzesze sympatyków tego typu eventów. Jako przykład można chociażby wskazać 71e Festival IN d’Awinion, który w 2017 roku odwiedziło ponad 150 tys. widzów. Pobyt na danym festiwalu wiąże się z potrzebą zaspokojenia podstawowych potrzeb, takich jak chociażby sen czy głód, co generuje kolejne zyski uzyskane z oferowanych usług hotelowych i gastronomicznych.

Duże znaczenie dla rozwoju obszaru i branży turystycznej ma bardzo dobrze rozbudowana infrastruktura transportowa. Dotyczy to nie tylko departamentu Vaucluse, ale i całej Francji. Rozbudowana sieć autostrad, prężnie działająca kolej dużych prędkości oraz strategicznie rozmieszczone lotniska to tylko kilka z przykładów inwestycji państwa w szybkie, a zarazem komfortowe przemieszczanie się z miejsca na miejsce. Krótszy czas podróży zachęca do podróżowania pomiędzy regionami nie tylko w ramach dłuższych wyjazdów, ale także weekendowych czy jednodniowych. Według danych na stronie narodowego francuskiego przewoźnika (SNCF) trasę z Paryża do Awinionu (ponad $700 \mathrm{~km}$ ) na pokładzie TGV można pokonać w 2 godziny 55 minut (TGV France, 2018). Droga Lyon-Awinion (233 km) zajmuje tym samym środkiem transportu nieco ponad godzinę. Dojechanie samochodem do departamentu Vaucluse również nie jest problematyczne. Jak zostało wcześniej wspomniane, miasta Francji są połączone ze sobą gęstą siecią dróg ekspresowych i autostrad, co na chwilę obecną jest nieosiągalne przez biedniejsze kraje, jak np. Polska. Daje to możliwość płynnego poruszania się po kraju turystów z Europy i spoza niej. Vaucluse jest także dogodnym miejscem wypadowym nad Morze Śródziemne, gdyż do najbliższych plaż w okolicach Marsylii można dotrzeć już w niespełna godzinę. Transport lotniczy jako trzeci środek lokomocji też nie ustępuje pozostałym - do wspomnianego rejonu można dostać się z lotnisk położonych w miejscowościach niedaleko samego departamentu, jak np. Toulon, Montpellier, Nimes czy nieco dalej usytuowana Marsylia.

Całość dopełnia umiejętnie przeprowadzona promocja departamentu, gdyż niezwykle ciekawa i starannie przemyślana kampania reklamowa, bogata w ulotki, prospekty i strony internetowe zachęca do skorzystania z oferty turystycznej, jaką Vaucluse może zaproponować potencjalnym wycieczkowiczom. Co ciekawe, nie poleca się jednego charakterystycznego miejsca, ale traktuje się region jako wspólną całość, gdzie każdy zabytek czy wydarzenie kulturalne wzajemnie się uzupełniają. Reklama zdecydowanie pomaga pokazać atrakcyjność i wyjątkowość obszaru na tle innych, co w tej części Francji nie jest prostym zadaniem.

\section{STRATEgIA ROZWOJU VAUCLUSE NA LATA 2025-2040}

Agencja Rozwoju Departamentu Vaucluse (Chiffres clefs du Tourisme Vauclusien 2017, 2018) opracowała w 2017 roku strategię rozwoju regionu do 2040 roku (Project..., 
2018), w której silny nacisk kładzie się na czwarty sektor gospodarki, jakim jest turystyka. W dokumencie zaakcentowano również konieczność działania w myśl idei poszanowania i poprawy jakości środowiska naturalnego. Zapis ten dotyczy zachowania różnorodności geograficznej, krajobrazowej, bogactwa ekologicznego obszaru, a także dziedzictwa naturalnego, historycznego i architektonicznego. Władze miasta zdają sobie sprawę, iż turystyka jest ogromnym atutem ekonomicznym departamentu i aby ten aspekt wykorzystać, niezbędne jest większe zróżnicowanie i udoskonalenie wszelkiej infrastruktury z nią związanej. Samo Vaucluse według strategii charakteryzuje się ekonomią silnie zorientowaną na usługi przeznaczone dla ludności, która może dzięki temu korzystać z wysokiej jakości życia oraz materialnego i niematerialnego dziedzictwa kulturowego. Utrzymanie takiego stanu rzeczy jest dla departamentu ważnym celem na kolejne lata, podobnie jak zorientowanie na turystykę. W tym celu będzie on wspierał inicjatywy i projekty związane z osiągnięciem doskonałości w dwóch dziedzinach:

- naturalność - wiążąca się z oparciem na lokalnych produktach i zasobach Vaucluse, $w$ tym upowszechnienie agronauki, podnoszenie kompetencji z zakresu rolnictwa (uprawa winorośli, energia odnawialna, produkty rolno-spożywcze, kosmetyki i działania ekologiczne);

- kultura i technika francuska - kreatywna i innowacyjna gospodarka (w tym branża cyfrowa, kulturalna, promowanie dziedzictwa w odniesieniu do turystyki i marketingu terytorialnego).

Strategia rozwoju turystycznego w najbliższych latach będzie obejmować przede wszystkim:

- waloryzację różnorodności działań turystycznych (turystyka winiarska, agroturystyka, turystyka biznesowa);

- podniesienie jakości dziedzictwa kulturowego (dotyczącej m.in. festiwalów w Awinionie i Orange);

- rozbudowanie aktywności na świeżym powietrzu (wycieczki piesze, turystyka rowerowa);

- utworzenie zintegrowanych szlaków turystycznych i parków rozrywki;

- wdrożenie i rozwój cyfrowych metod w dziedzinie turystki (wirtualna rzeczywistość, przewodniki audio);

- strukturyzacja sektora usług, kultury, dziedzictwa i sportu;

- rozwój terytorialny oparty na kreatywności i innowacyjności;

- utworzenie nowych miejsc pracy w turystyce;

- wspieranie działalności proekologicznej;

- kreowanie dobrego wizerunku regionu w kraju i za granicą.

\section{ZAKOŃCZENIE}

Branża turystyczna stanowi dla Vaucluse szansę na rozwój gospodarczy regionu. Dzięki wykorzystaniu nowoczesnego i innowacyjnego podejścia do turystyki departament ma możliwość konkurować z innymi obszarami o turystów z kraju i z zagranicy. Eksponowanie walorów naturalnych oraz dziedzictwa materialnego i niematerialnego czyni omawiane miejsce atrakcyjnym i ciekawym, a co za tym idzie, popularnym na tle innych departamentów Francji.

Powyższe opracowanie pozwoliło na przedstawienie najważniejszych wniosków dotyczących turystyki i jej wpływu na rozwój departamentu Vaucluse: 
- niezwykle ważne dla podnoszenia atrakcyjności obszaru jest inwestowanie w infrastrukturę turystyczną i wydarzenia kulturalne,

- baza noclegowa, gastronomiczna i usługi, pomimo już wysokiej jakości, muszą być udoskonalane i rozwijane w kierunku potrzeb i upodobań turystów z całego świata,

- należy dbać o tradycję i kultywować produkty regionalne - zarówno rękodzieło, jak i artykuły spożywcze (wina, sery i potrawy),

- innowacyjność i otwartość w promowaniu turystyki i obiektów zabytkowych jest wskazana w celu podnoszenia konkurencyjności regionu,

- wprowadzenie nowoczesnej technologii (w rodzaju przewodników wideo i audio oraz rozszerzonej rzeczywistości) znacznie wpływa na liczbę turystów zainteresowanych zwiedzaniem obiektów,

- waloryzacja działań turystycznych powinna być przeprowadzana co roku w celu sprawdzenia poprawności ich działania,

- wspieranie turystyki w departamencie może pomóc w tworzeniu nowych miejsc pracy,

- Vaucluse powinno skupić się również na inwestowaniu i promowaniu dziedzictwa kulturowego regionu (m.in. festiwale),

- rozbudowane atrakcje na świeżym powietrzu (wycieczki piesze, narciarstwo, sporty rowerowe) są ważnym czynnikiem wspierającym rozwój turystyki,

- kapitał zgromadzony z turystyki daje szanse rozwoju zarówno w zakresie infrastruktury drogowej, jak i turystycznej (np. budowa sieci tramwajowej w Awinionie),

- konkurencyjność obszaru na tle innych możliwa jest dzięki kreatywnemu i sprawnemu marketingowi regionalnemu,

- atrakcyjny turystycznie obszar jest częściej i chętniej odwiedzany przez turystów,

- dbanie o jakość usług i zadowolenie klientów powinno być priorytetem w planach rozwoju departamentu.

Miliony euro zostawiane co roku przez odwiedzających pozwalają na podnoszenie jakości wszystkich aspektów zmierzających do rozwoju regionalnego obszaru. Przed Vaucluse jeszcze daleka droga do osiągnięcia optimum możliwości turystycznych, co pozwala na opracowywanie planów na przyszłość z silnym naciskiem na innowacyjność i ochronę przyrody. To właśnie tworzenie strategii w myśl zrównoważonego rozwoju pozwoli na ochronę dziedzictwa i dbałość o tradycję regionalną, jaką jest niewątpliwie produkcja win. Departament Vaucluse jest sztandarowym przykładem obszaru, który potrafi dostosować swoją gospodarkę do możliwości i ograniczeń regionalnych.

\section{Literatura \\ References}

Chiffres clefs du Tourisme Vauclusien 2017 (2018, 10 października). Pozyskano z http://vaucluseprovence-attractivite.com/observation-touristique/

Delekta, A., Dorocki, S., Zdon-Korzeniowska, M. (2012). Atrakcyjność turystyczna regionów na przykładzie Francji. Annales Universitatis Paedagogicae Cracoviensis Studia Geographica, 3, 7-25.

Dorocki, S., Brzegowy, P. (2013). Rozwój przemysłu turystycznego departamentów Francji zamorskiej w warunkach światowego kryzysu gospodarczego. Przedsiębiorczość-Edukacja, 9, 136-160. 
Głuszczuk, D. (2011). Istota rozwoju regionalnego i jego determinanty. Ekonomia = Economics, 5(17), 68-80.

Januszewska, M., Nawrocka, E. (2015). Wpływ turystyki na rozwój lokalny. Prace Naukowe Uniwersytetu Ekonomicznego we Wrocławiu, 379, 23-31. DOI: 10.15611/pn.2015.379.02

La fréquentation touristique (2018, 10 października). Pozyskano z http://vaucluseprovence-attractivite.com/observation-touristique/

Le tourisme en Vaucluse (2018, 10 października). Pozyskano z https://www.insee.fr/fr/statistiques $/ 3303636$ ?sommaire $=3353488 \& q=$ tourisme

Łazarek, R. (1999). Ekonomika turystyki. Warszawa: Zakład Wydawniczy DrukTur.

Markowski, T. (2008). Teoretyczne podstawy rozwoju lokalnego i regionalnego. W: Z. Strzelecki (red.). Gospodarka regionalna i lokalna. Warszawa: Wydawnictwo Naukowe PWN.

Projet de stratégie Vaucluse 2025-2040 (2018). Pozyskano z http://www.vaucluse.fr/fileadmin/ user_upload/pdf_docs/e_cadre_de_vie/Vaucluse_2025-2040/STRATEGIE-22.09.17.pdf

TGV France (2018, 10 listopada). Pozyskano z https://en.oui.sncf/en/tgv-france-brussels

Katarzyna Janczarska-Bergel, mgr, Uniwersytet Pedagogiczny w Krakowie, Instytut Geografii, Zakład Dydaktyki Geografii. Absolwentka Instytutu Geografii Uniwersytetu Pedagogicznego w Krakowie (2017). Doktorantka w Instytucie Geografii Uniwersytetu Pedagogicznego. Zainteresowania badawcze autorki dotyczą rozwoju regionalnego Francji, ekologii i dydaktyki geografii.

Katarzyna Janczarska-Bergel, MSc, Pedagogical University of Cracow, Institute of Geography, Department of Geography Didactics. A graduate of the Institute of Geography of the Pedagogical University of Cracow (2017). A doctoral student at the Institute of Geography of the Pedagogical University of Cracow. The author's research interests include regional development of France, ecology and geography didactics.

ORCID: 0000-0002-6075-0167

Adres/address:

Uniwersytet Pedagogiczny w Krakowie

Instytut Geografii

Zakład Dydaktyki Geografii

ul. Podchorążych 2, 30-084 Kraków, Polska

e-mail: katarzyna-bergel@wp.pl 